\title{
Prognostic significance of CD133 and ABCB5 expression in papillary thyroid carcinoma
}

\author{
Maria Augusta Karas Zella, ${ }^{1}$ Ana Paula Martins Sebastião, ${ }^{2}$ Luiz Martins Collaço, ${ }^{3}$ Daniel Cury Ogata, ${ }^{4}$ \\ Guilherme Cecchetti, ${ }^{5}$ Ivan José Paredes Bartolomei, ${ }^{5}$ Ana Maria Waaga-Gasser, ${ }^{6}$ \\ Carmen Australia Paredes Marcondes Ribas ${ }^{5}$ \\ ${ }^{1}$ Medical Research Institute, Mackenzie Evangelical School of Medicine, Curitiba, Paraná, Brazil \\ ${ }^{2}$ Department of Pathology, Nossa Senhora das Graças Hospital, Curitiba, Paraná, Brazil; \\ ${ }^{3}$ Department of Pathology, Mackenzie Evangelical School of Medicine, Curitiba, Paraná, Brazil \\ ${ }^{4}$ Department of Pathology, Universidade do Vale do Itajaí, Santa Catarina, Brazil \\ ${ }^{5}$ Mackenzie Evangelical School of Medicine, Curitiba, Paraná, Brazil \\ ${ }^{6}$ Renal Division, Brigham and Women's Hospital, Harvard Medical School, Boston, MA, USA
}

\begin{abstract}
Expression of CD133 and ABCB5 is associated with tumor aggressiveness, but evidence in papillary thyroid cancer (PTC) is lacking. We correlated CD133 and ABCB5 expression with pathological characteristics and factors of worse prognosis in PTC. Samples of 119 PTCs and 40 controls (goiters) were distributed in 8 tissue microarray blocks and evaluated with immunohistochemistry using anti-CD133 and anti-ABCB5 antibodies. The expression of each marker alone and combined was analyzed against pathological characteristics and factors of worse prognosis in PTC. Expression of CD133 alone (19 tumors, 16.0\%) was more frequent in patients with versus without lymph node metastases $(\mathrm{P}=0.024)$. Expression of $\mathrm{ABCB} 5$ alone $(\mathrm{n}=95,83.3 \%)$ was associated with larger tumor size $(\mathrm{P}=0.045)$. $\mathrm{CD} 133-\mathrm{ABCB} 5$ coexpression was not associated with pathological characteristics or factors of worse prognosis in PTC.
\end{abstract}

Key words: CD133 protein, human; prominin 1 protein, human; ATP-binding cassette transporter, subfamily B; ABCB5 protein, human; immunohistochemistry; cancer; papillary thyroid.

Correspondence: Maria Augusta Karas Zella, Medical Research Institute, Mackenzie Evangelical School of Medicine, Alameda Augusto Stellfeld 1980, CEP 80730150, Curitiba, Paraná, Brazil. Tel. +55.4132405488. E-mail: makzella@hotmail.com

Contributions: MAKZ, conception and design, analysis and interpretation of the data; drafting of the article, critical revision of the article for important intellectual content, final approval of the article; APMS, conception and design; drafting of the article; critical revision of the article for important intellectual content; final approval of the article. LMC, conception and design, drafting of the article, critical revision of the article for important intellectual content, final approval of the article; DCO, substantial contributions to acquisition of data and analysis and interpretation of data; GC, analysis and interpretation of the data, drafting of the article. IJPB: conception and design; drafting of the article. AMWG, conception and design, critical revision of the article for important intellectual content, final approval of the article; CAPMR, conception and design; final approval of the article. All the authors have read and approved the final version of the manuscript and agreed to be accountable for all aspects of the work.

Conflict of interest: The authors declare no conflict of interest.

Availability of data and materials: The data used to support the findings of this study are available from the corresponding author upon request.

Funding: This study was funded by Mackenzie Evangelical College of Paraná (Curitiba, Paraná, Brazil) and partially funded by the Coordenação de Aperfeiçoamento de Pessoal de Nível Superior - Brasil (CAPES) - Finance Code 001.

Ethics approval and consent to participate: The Institution's Research Ethics Committee approved the study protocol (1.999.671), and all patients signed an informed consent form. The procedures followed were in accordance with the ethical standards of the responsible committee on human experimentation (institutional and national) and with the Helsinki Declaration of 1975, as revised in 2013. 


\section{Introduction}

Survival rates of papillary thyroid carcinoma (PTC) are $>90 \%$ over 10 years. ${ }^{1-4}$ However, up to $90 \%$ of the patients with PTC have cervical lymph node metastases, which are associated with an increased risk of locoregional recurrence and distant metastases. ${ }^{5,6}$ Recognition of PTCs with increased aggressive behavior allows for proper patient follow-up, ${ }^{7}$ but new immunohistochemical biomarkers are needed to identify PTC cases with unfavorable prognosis. The pentaspan membrane glycoprotein CD133 (or prominin-1) has been used to identify cancer stem cells in various types of cancer $^{8,9}$ and has been associated with worse prognosis. ${ }^{10,11}$ In young individuals with differentiated thyroid carcinoma, CD133 expression has been associated with tumor size, lymph node metastases, and BRAF mutation. ${ }^{12}$ Expression of this protein is also associated with other markers, including the ATP-binding cassette subfamily B member 5 (ABCB5), ${ }^{13,14}$ which has been associated with worse prognosis and vascular invasion in colorectal carcinomas. ${ }^{15}$ To the best of our knowledge, the expression of $\mathrm{ABCB} 5$ and the coexpression of CD133 and ABCB5 have still not been evaluated in PTCs. The aim of this study was to correlate the expression of CD133 and ABCB5 with pathological characteristics and prognosis of PTC.

\section{Materials and Methods}

\section{Cases}

A search of pathology records identified 154 patients with PTC who had undergone thyroidectomy between January $1^{\text {st }}, 2002$, and December $31^{\text {st }}, 2017$, across three hospitals in Curitiba (Brazil). Forty cases of multinodular goiter served as controls. Clinical and histopathological data (including patients' age, presence of lymph node metastasis, and distant metastasis) were obtained from medical records and pathology reports. The 2017 American Joint Committee on Cancer (AJCC)/TNM staging system for differentiated thyroid carcinomas was used for tumor staging and classification. ${ }^{4}$

\section{Histological evaluation}

Hematoxylin-eosin stained slides with tumor samples were reviewed by an independent pathologist blinded to the clinical history of the patients to confirm the diagnosis, identify the area of the tumor, and select representative paraffin block regions for the construction of tissue microarray (TMA) blocks.

Histological subtypes of PTC were identified according to the World Health Organization (WHO) 2017 criteria. ${ }^{16}$ The evaluation of the tumors included the observation of the presence or absence of capsule, capsular invasion, tumor size, angiolymphatic invasion, microscopic and macroscopic extrathyroidal extension, and presence or absence of tumor multifocality (i.e., presence of two or more tumor foci in the same lobe or in both lobes). ${ }^{17}$ The total number of lymph nodes removed, and the presence of metastatic lymph nodes were recorded.

\section{Tissue microarray}

For TMA assembly, we identified the best represented areas of the neoplasm in the original slides and matched these areas with the paraffin blocks. We then extracted a cylinder of tissue from the area selected using the Tissue-Tek Quick-Ray (Sakura Finetek USA Inc., Torrance, CA, USA) handheld device coupled with a 2mm diameter forceps. The samples were then mapped and organized in TMAs, and control tissue (placenta fragment) was added to the first spot in the TMA blocks to mark the starting point for slide reading. The TMA blocks were cut at $5 \mu \mathrm{m}$ thickness using a microtome, placed on Superfrost Plus (hydrophilic) slides (ThermoFisher Scientific, Braunschweig, Germany) and counterstained with hematoxylin. The samples were then mapped and organized in TMAs, and control tissue (placenta fragment) was added to the first spot in the TMA blocks to mark the starting point for slide reading.

\section{Immunohistochemistry}

The slides with the TMA blocks were submitted to the immunoperoxidase technique (Benchmark Ultra, Roche Diagnostics, Indianapolis, IN, USA) with 3-in-1 integrated processing including deparaffinization, rehydration, and antigen recovery, and use of the Cell Conditioning 1 (high $\mathrm{pH}$ ) and 2 (low $\mathrm{pH})$ buffers (Roche Diagnostics GmbH, Mannheim, Germany). The slides were incubated with primary antibodies for 16-20 min at room temperature. Amplification was performed by ultraView Universal DAB Detection Kit (Roche Diagnostics GmbH). DAB was used as a chromogen and hematoxylin as a counterstain. The samples were processed on the Benchmark Ultra automated platform using an anti-CD133 polyclonal antibody (Biorbyt, Cambridge, UK) diluted at 1:100 and anti-ABCB5 antibody (clone 5H3C6; GeneTex, Irvine, CA, USA) diluted at 1:750.

Expression of CD133 and ABCB5 was defined by the presence (positive) or absence (negative) of immunoreactivity in the cell membrane or cytoplasm. The intensity scores were 0 (no staining), 1 (weak staining), 2 (moderate staining), and 3 (strong staining). Each slide was evaluated by two pathologists who separately observed 10 high power fields. A microscopic conference was held to discuss discrepancies and reach a consensus.

Categorical variables are summarized as absolute and percentage frequencies, and continuous variables as mean ( \pm SD) and median (minimum and maximum) values. Chi-square test or Fisher's exact test verified associations between two categorical variables, and the Mann-Whitney test compared groups of continuous variables. Results are expressed as odds ratios (OR) and 95\% confidence intervals (95\% CIs). The analyses were performed using Statistica (version 7; Statsoft Inc., Tulsa, OK, USA), SPSS (version 19; SPSS Inc., Chicago, IL, USA), and BioEstat (version 5; Instituto Mamirauá, Manaus, Brazil). The significance level was set at $5 \%$.

\section{Results}

Of the 154 samples, 35 were excluded due to detachment of the histological section from the slide during immunohistochemical processing, absence of tumor cells in the TMA section, low tumor volume, or absence of immunohistochemical reaction. The final analysis included 119 cases of PTC and 40 controls. In all, 35.3\% $(n=42)$ of the tumors were $\leq 1 \mathrm{~cm}, 24.4 \%(n=29)$ of the patients had metastases to locoregional lymph nodes (N1), and 5.0\% $(\mathrm{n}=6)$ had distant (lung) metastases on ${ }^{131} \mathrm{I}$ whole-body scan (Table 1). The median follow-up was 36.5 months (0-241 months).

The most frequent PTC variants were classic, follicular, and papillary microcarcinoma. Uncommon variants $(6.5 \%, n=8)$ included tall cell $(n=3)$, oncocytic $(n=3)$, Warthin-like $(n=1)$, and macrofollicular $(\mathrm{n}=1)$.

\section{CD133 expression}

CD133 expression was analyzed in all 119 cases and was positive in $19(16.0 \%)$ samples (Table 2). The expression was observed in the cell membrane and cytoplasm (Figure 1) at low intensity (score 1, weak staining) and was more frequent among 
patients with ( $\mathrm{n}=9$ of 29$)$ versus without $(\mathrm{n}=10$ of $90 ; \mathrm{P}=0.024)$ lymph node metastases (Table 3 ). CD133 expression had no correlation with other markers of disease severity (Table 2).

\section{ABCB5 expression}

ABCB5 expression was analyzed in 114 cases and was positive in $95(83.3 \%$ ) samples (Table 2), all at the cell membrane (Figure 1) and at different degrees of intensity. Compared with tumors without $\mathrm{ABCB} 5$ expression, those expressing $\mathrm{ABCB} 5$ were larger ( $1.23 \pm 0.85 \mathrm{~cm}$ versus $1.93 \pm 41.48 \mathrm{~cm}$, respectively, $\mathrm{P}=0.045)$. No other association was found between $\mathrm{ABCB} 5$ expression and other markers of disease severity (Table 2).

\section{CD133-ABCB5 coexpression}

Fifteen patients (12.6\%) had tumors expressing both CD133 and ABCB5 (Table 4). Expression of both markers compared with expression of only one or none of the markers was not associated with increased frequency of any risk factor of disease severity.

\section{CD133 and $A B C B 5$ expression in papillary tumors compared with goiter}

Among samples obtained from patients with goiter in the control group, 5 (12.5\%) expressed CD133 and 15 (37.5\%) expressed ABCB5 (Table 5, Figure 1). Expression of ABCB5 was more frequent in patients with PTC versus goiter (OR 8.33, 95\% CI 3.71$18.69, \mathrm{P}<0.0001$ ), but the same was not observed for CD133 (OR $1.33,95 \%$ CI $0.46-3.83, \mathrm{P}=0.78)$.

\section{Discussion}

Increased CD133 expression in PTC has been associated with early lymph node metastases and advanced TNM stages in some ${ }^{18}$ but not all studies, ${ }^{19}$ and with poor prognosis in medullary thyroid carcinoma. ${ }^{20}$ Additionally, CD133 has been shown in vitro to promote the self-renewal capacity of anaplastic thyroid cancer cell lines. ${ }^{21}$ The prevalence of positive CD133 among our patients was low, but expression of this marker increased by 3.6 times the odds of metastatic lymph nodes. If this finding is confirmed in larger samples and extended to cytopathological analysis, CD133 may emerge as a pivotal presurgical diagnostic tool to identify patients benefiting from a more extensive neck dissection. Interestingly, the suppression of ABCB5 sensitizes cells for uptake of doxorubicin and cell apoptosis, ${ }^{22}$ implying that the expression of both CD133 and $\mathrm{ABCB} 5$ may be associated with worse clinical course.

Table 1. Clinical characteristics of the patients evaluated for CD133 and ABCB5 expression

\begin{tabular}{lcc} 
& $\begin{array}{c}\text { CD133 } \\
(\mathrm{n}=119)\end{array}$ & $\begin{array}{c}\text { ABCB5 } \\
(\mathrm{n}=114)\end{array}$ \\
Age on diagnosis (years) & $45.45 \pm 13.32$ & $44.92 \pm 12.71$ \\
Gender & & \\
$\quad$ Female & $83.19 \%(\mathrm{n}=99)$ & $82.45 \%(\mathrm{n}=94)$ \\
$\quad$ Male & $16.80 \%(\mathrm{n}=20)$ & $17.54 \%(\mathrm{n}=20)$ \\
\hline Tumor size & & \\
$\quad$ 1cm & $35.29 \%(\mathrm{n}=42)$ & $35.96 \%(\mathrm{n}=41)$ \\
$\quad>1 \mathrm{~cm}$ & $64.7 \%(\mathrm{n}=77)$ & $64 \%(\mathrm{n}=73)$ \\
Distant metastases on diagnosis & $5.04 \%(\mathrm{n}=6)$ & $5.26 \%(\mathrm{n}=6)$ \\
\hline Lymph node metastases (N1) & $24.36 \%(\mathrm{n}=29)$ & $23.52 \%(\mathrm{n}=28)$ \\
Age $\geq 55$ years on diagnosis & $23.52 \%(\mathrm{n}=28)$ & $21.05(\mathrm{n}=24)$ \\
\hline AJCC/TNM 8 ${ }^{\text {th }}$ edition $(2017)$ & & \\
I + II $>55$ years & $22.68 \%(\mathrm{n}=27)$ & $20.17 \%(\mathrm{n}=23)$ \\
III + IVa + IVb $>55$ years & $0.84 \%(\mathrm{n}=01)$ & $0.87 \%(\mathrm{n}=1)$ \\
I $<55$ years & $72.26 \%(\mathrm{n}=86)$ & $74.56 \%(\mathrm{n}=85)$ \\
II $<55$ years & $4.20 \%(\mathrm{n}=5)$ & $4.38 \%(\mathrm{n}=5)$ \\
\hline
\end{tabular}

Table 2. Pathological characteristics of papillary thyroid carcinoma in relation to CD133 and ABCB5 immunoreactivity.

\begin{tabular}{|c|c|c|c|c|c|c|}
\hline & $\begin{array}{c}\text { CD133 } \\
\text { negative }\end{array}$ & $\begin{array}{c}\text { CD133 } \\
\text { positive }\end{array}$ & $\mathbf{P}$ & $\begin{array}{c}\text { ABCB5 } \\
\text { negative }\end{array}$ & $\begin{array}{c}\text { ABCB5 } \\
\text { positive }\end{array}$ & $\mathbf{P}$ \\
\hline Samples, \% (n) & $84 \%(n=100)$ & $16.0 \%(\mathrm{n}=19)$ & 0.00001 & $16.7 \%(n=19)$ & $83.3 \%(n=95)$ & 0.00001 \\
\hline Age (years), mean $\pm \mathrm{SD}$ & $45.9 \pm 13.7$ & $43.1 \pm 11$ & - & $46.2 \pm 10.4$ & $44.7 \pm 13.1$ & - \\
\hline Male sex, \%(n) & $14(14 \%)$ & $6(31.58 \%)$ & 0.067 & $5.6 \%(\mathrm{n}=1)$ & $20 \%(n=19)$ & 0.107 \\
\hline $\begin{array}{l}\text { Variants } \\
\text { Classic } \\
\text { Follicular } \\
\text { Papillary microcarcinoma } \\
\text { Others }\end{array}$ & $\begin{array}{c}36 \%(n=36) \\
22 \%(n=22) \\
35 \%(n=35) \\
7 \%(n=7)\end{array}$ & $\begin{array}{c}42.10 \%(\mathrm{n}=8) \\
15.79 \%(\mathrm{n}=3) \\
36.84 \%(\mathrm{n}=7) \\
5.26 \%(\mathrm{n}=1)\end{array}$ & $\begin{array}{l}0.61 \\
0.40 \\
0.88 \\
0.62\end{array}$ & $\begin{array}{l}31.58 \%(n=6) \\
10.53 \%(n=2) \\
47.37 \%(n=9) \\
10.53 \%(n=2)\end{array}$ & $\begin{array}{c}37.89 \%(\mathrm{n}=36) \\
22.10 \%(\mathrm{n}=21) \\
33.68 \%(\mathrm{n}=32) \\
6.31 \%(\mathrm{n}=6)\end{array}$ & $\begin{array}{l}0.60 \\
0.21 \\
0.26 \\
0.40\end{array}$ \\
\hline Tumor size $(\mathrm{cm})$ & $1.79 \pm 1.38$ & $1.86 \pm 1.11$ & 0.84 & $1.23 \pm 0.85$ & $1.93 \pm 1.48$ & 0.045 \\
\hline $\begin{array}{l}\text { T staging } \\
\text { Tla } \\
\text { T1b } \\
\text { T2 } \\
\text { T3 }\end{array}$ & $\begin{array}{c}35 \%(\mathrm{n}=35) \\
38 \%(\mathrm{n}=38) \\
22 \%(\mathrm{n}=22) \\
5 \%(\mathrm{n}=5)\end{array}$ & $\begin{array}{c}36.84 \%(\mathrm{n}=7) \\
21.05 \%(\mathrm{n}=4) \\
36.84 \%(\mathrm{n}=7) \\
5.26 \%(\mathrm{n}=1)\end{array}$ & $\begin{array}{l}0.88 \\
0.16 \\
0.17 \\
0.66\end{array}$ & $\begin{array}{c}47.37 \%(n=9) \\
42.10 \%(n=8) \\
10.53 \%(n=2) \\
0 \%(n=0)\end{array}$ & $\begin{array}{c}33.68 \%(\mathrm{n}=32) \\
33.68 \%(\mathrm{n}=32) \\
25.26 \%(\mathrm{n}=24) \\
7.37 \%(\mathrm{n}=7)\end{array}$ & $\begin{array}{l}0.26 \\
0.48 \\
0.16 \\
0.27\end{array}$ \\
\hline $\begin{array}{l}\text { N staging } \\
\text { N1 } \\
\text { M1 } \\
\text { Unifocal } \\
\text { Multifocal }\end{array}$ & $\begin{array}{c}20 \%(\mathrm{n}=20) \\
5 \%(\mathrm{n}=5) \\
57 \%(\mathrm{n}=57) \\
43 \%(\mathrm{n}=43)\end{array}$ & $\begin{array}{c}47.37 \%(\mathrm{n}=9) \\
5.26 \%(\mathrm{n}=1) \\
63.16 \%(\mathrm{n}=16) \\
36.84 \%(\mathrm{n}=7)\end{array}$ & $\begin{array}{c}0.011 \\
0.66 \\
0.62 \\
0.62\end{array}$ & $\begin{array}{c}21.05 \%(n=4) \\
10.53 \%(n=2) \\
68.42 \%(n=13) \\
31.58 \%(n=6)\end{array}$ & $\begin{array}{c}25.26 \%(\mathrm{n}=24) \\
4.21 \%(\mathrm{n}=4) \\
57.89 \%(\mathrm{n}=55) \\
41.11 \%(\mathrm{n}=40)\end{array}$ & $\begin{array}{l}0.47 \\
0.26 \\
0.39 \\
0.39\end{array}$ \\
\hline Microscopic extension & $14 \%(n=14)$ & $26.31 \%(\mathrm{n}=5)$ & 0.16 & $15.79 \%(\mathrm{n}=3)$ & $17.89 \%(\mathrm{n}=17)$ & 0.82 \\
\hline Macroscopic extension & $3 \%(n=3)$ & $5.26 \%(\mathrm{n}=1)$ & 0.51 & $0 \%(\mathrm{n}=0)$ & $5.26 \%(\mathrm{n}=5)$ & 0.39 \\
\hline Capsular invasion & $1 \%(\mathrm{n}=1)$ & $0 \%(\mathrm{n}=0)$ & 0.85 & $15.79 \%(\mathrm{n}=3)$ & $7.37 \%(\mathrm{n}=7)$ & 0.22 \\
\hline Angiolymphatic invasion & $27 \%(n=27)$ & $36.84 \%(n=7)$ & 0.38 & $31.58 \%(n=6)$ & $33.68 \%(n=32)$ & 0.86 \\
\hline
\end{tabular}


However, coexpression of CD133 and ABCB5 in our study was not useful in recognizing markers of disease severity in PTC when compared with expression of each marker alone or none of the markers.

Although limited by the retrospective design and small number of patients with metastatic lymph nodes, our study showed that patients with PTC expressing CD133 have higher odds of lymph node metastases, while tumors expressing ABCB5 are larger than those not expressing this marker. CD133-ABCB5 coexpression was no more helpful than expression of each marker alone or none of the markers in identifying patients with markers of disease severity.

Table 3. Analysis of the association between the presence (+) or absence (-) of expression of each marker (CD133 and ABCB5) alone or in combination versus presence or absence of lymph node metastasis.

\begin{tabular}{|c|c|c|c|c|}
\hline & Lymph n & scted & Odds ratio & \\
\hline & Yes $(n=29)$ & No $(\mathrm{n}=90)$ & ( $95 \%$ confidence interval) & $\mathbf{P}$ \\
\hline CD133+ & $31.03 \%(n=9)$ & $11.11 \%(n=10)$ & $3.60(1.29-10.03)$ & 0.024 \\
\hline CD133- & $68.97 \%(n=20)$ & $88.89 \%(\mathrm{n}=80)$ & $0.28(0.10-0.77)$ & \\
\hline CD133+/ABCB5+ & $24.14 \%(n=7)$ & $8.42 \%(\mathrm{n}=8)$ & $3.26(1.07-9.98)$ & 0.067 \\
\hline CD133+/ABCB5- & $6.90 \%(n=2)$ & $0 \%(\mathrm{n}=0)$ & - & - \\
\hline CD133-/ABCB5+ & $58.62 \%(\mathrm{n}=17)$ & $65.56 \%(\mathrm{n}=59)$ & $0.74(0.32-1.75)$ & 0.65 \\
\hline CD133-/ABCB5- & $6.90 \%(\mathrm{n}=2)$ & $14.44 \%(n=13)$ & $0.44(0.09-2.07)$ & 0.46 \\
\hline ABCB5+ & $85.71 \%(\mathrm{n}=24)$ & $85.56 \%(\mathrm{n}=71)$ & $1.27(0.38-4.9)$ & 0.92 \\
\hline ABCB5- & $14.29 \%(\mathrm{n}=4)$ & $17.44 \%(\mathrm{n}=15)$ & $0.79(0.24-2.61)$ & \\
\hline
\end{tabular}

Table 4. Pathological characteristics of the tumors in relation to the presence $(+)$ or absence $(-)$ of expression of each marker (CD133, $\mathrm{ABCB} 5)$ alone or in combination.

\begin{tabular}{|c|c|c|c|c|c|c|c|}
\hline & CD133+/ABCB5+ & CD133+/ABCB5- & $P$ & CD133-/ABCB5+ & $\mathbf{P}$ & CD133-/ABCB5- & $\mathbf{P}$ \\
\hline Sample, \% (n) & $12.6 \%(n=15)$ & $1.68 \%(n=2)$ & 0.001 & $63.86 \%(\mathrm{n}=76)$ & 0.00001 & $12.6 \%(\mathrm{n}=15)$ & 1 \\
\hline $\begin{array}{l}\text { Variant } \\
\text { Classic } \\
\text { Follicular } \\
\text { Papillary microcarcinoma } \\
\text { Others }\end{array}$ & $\begin{array}{c}53.33 \%(\mathrm{n}=8) \\
13.33 \%(\mathrm{n}=2) \\
33.33 \%(\mathrm{n}=5) \\
0.00 \%(\mathrm{n}=0)\end{array}$ & $\begin{array}{c}0.00 \%(\mathrm{n}=0) \\
0.00 \%(\mathrm{n}=0) \\
20.00 \%(\mathrm{n}=1) \\
20.00 \%(\mathrm{n}=1)\end{array}$ & $\begin{array}{c}0.051 \\
0.55 \\
0.52 \\
0.25\end{array}$ & $\begin{array}{c}36.84 \%(n=28) \\
23.68 \%(n=18) \\
31.57 \%(n=24) \\
7.89 \%(n=6)\end{array}$ & $\begin{array}{l}0.22 \\
0.39 \\
0.87 \\
0.33\end{array}$ & $\begin{array}{c}33.33 \%(\mathrm{n}=5) \\
13.33 \%(\mathrm{n}=2) \\
46.66 \%(\mathrm{n}=7) \\
6.66 \%(\mathrm{n}=1)\end{array}$ & $\begin{array}{l}0.27 \\
0.70 \\
0.46 \\
0.31\end{array}$ \\
\hline Tumor size (cm) & $1.89 \pm 1.17$ & $1.10 \pm 0.57$ & 0.34 & $1.91 \pm 1.47$ & 0.84 & $1.24 \pm 0.93$ & 0.15 \\
\hline $\begin{array}{l}\text { T staging } \\
\text { Tla } \\
\text { T1b } \\
\text { T2 } \\
\text { T3 }\end{array}$ & $\begin{array}{c}33.33 \%(n=5) \\
20.00 \%(n=3) \\
40.00 \%(n=6) \\
6.67 \%(n=1)\end{array}$ & $\begin{array}{c}50.00 \%(n=1) \\
50.00 \%(n=1) \\
0.00 \%(n=0) \\
0.00 \%(n=0)\end{array}$ & $\begin{array}{l}0.52 \\
0.43 \\
0.40 \\
0.75\end{array}$ & $\begin{array}{c}31.58 \%(\mathrm{n}=24) \\
37.66 \%(\mathrm{n}=29) \\
23.37 \%(\mathrm{n}=18) \\
6.49 \%(\mathrm{n}=5)\end{array}$ & $\begin{array}{l}0.56 \\
0.15 \\
0.15 \\
0.67\end{array}$ & $\begin{array}{c}45.66 \%(n=7) \\
40 \%(n=6) \\
13.33 \%(n=2) \\
00 \%(n=0)\end{array}$ & $\begin{array}{l}0.46 \\
0.21 \\
0.11 \\
0.31\end{array}$ \\
\hline $\begin{array}{l}\text { N staging } \\
\text { Nx } \\
\text { N0 } \\
\text { N1 } \\
\text { M1 } \\
\text { Unifocal } \\
\text { Multifocal }\end{array}$ & $\begin{array}{c}60.00 \%(\mathrm{n}=9) \\
40.00 \%(\mathrm{n}=6) \\
13.33 \%(\mathrm{n}=2) \\
46.66 \%(\mathrm{n}=7) \\
0.00 \%(\mathrm{n}=0) \\
66.67 \%(\mathrm{n}=10) \\
33.33 \%(\mathrm{n}=5)\end{array}$ & $\begin{array}{c}40.00 \%(\mathrm{n}=2) \\
60.00 \%(\mathrm{n}=3) \\
0.00 \%(\mathrm{n}=0) \\
40 \%(\mathrm{n}=2) \\
20 \%(\mathrm{n}=01) \\
50 \%(\mathrm{n}=1) \\
50 \%(\mathrm{n}=1)\end{array}$ & $\begin{array}{l}0.40 \\
0.40 \\
0.55 \\
0.60 \\
0.25 \\
0.60 \\
0.52\end{array}$ & $\begin{array}{c}44.15 \%(\mathrm{n}=34) \\
55.84 \%(\mathrm{n}=43) \\
22.07 \%(\mathrm{n}=17) \\
22.07 \%(\mathrm{n}=17) \\
5.19 \%(\mathrm{n}=4) \\
56.38 \%(\mathrm{n}=43) \\
42.85 \%(\mathrm{n}=33)\end{array}$ & $\begin{array}{c}0.26 \\
0.26 \\
0.35 \\
0.053 \\
0.48 \\
0.47 \\
0.49\end{array}$ & $\begin{array}{c}33.33 \%(\mathrm{n}=5) \\
66.66 \%(\mathrm{n}=10) \\
20 \%(\mathrm{n}=3) \\
13.33 \%(\mathrm{n}=2) \\
6.66 \%(\mathrm{n}=1) \\
66.67 \%(\mathrm{n}=10) \\
33.33 \%(\mathrm{n}=5)\end{array}$ & $\begin{array}{c}0.14 \\
0.14 \\
0.50 \\
0.054 \\
0.31 \\
1.0 \\
1.0\end{array}$ \\
\hline Microscopic extension & $33.33 \%(\mathrm{n}=5)$ & $0.00 \%(\mathrm{n}=0)$ & 0.29 & $14.28 \%(\mathrm{n}=11)$ & 0.08 & $20 \%(\mathrm{n}=3)$ & 0.34 \\
\hline Macroscopic extension & $6.67 \%(\mathrm{n}=1)$ & $0.00 \%(n=0)$ & 0.75 & $3.89 \%(\mathrm{n}=3)$ & 0.52 & $00 \%(n=0)$ & 0.31 \\
\hline Capsular invasion & $0.00 \%(\mathrm{n}=0)$ & $20.00 \%(\mathrm{n}=1)$ & 0.25 & $7.79 \%(\mathrm{n}=6)$ & 0.33 & $20 \%(\mathrm{n}=3)$ & 0.11 \\
\hline Angiolymphatic invasion & $40.00 \%(n=6)$ & $40.00 \%(n=2)$ & 0.70 & $31.16 \%(n=24)$ & 0.35 & $20 \%(\mathrm{n}=3)$ & 0.21 \\
\hline
\end{tabular}

Table 5. Expression of CD133 and ABCB5 in the papillary thyroid cancer (PTC) and goiter (control) groups.

\begin{tabular}{lccccc} 
& PTC group & Control group & Odds ratio $(95 \%$ confidence interval) & P \\
Positive CD133, \% (n) & $16.0 \%(\mathrm{n}=19)$ & $12.5 \%(\mathrm{n}=5)$ & $1.33(0.46-3.83)$ & 0.78 \\
Positive ABCB5,\%(n) & $83.3 \%(\mathrm{n}=95)$ & $37.5 \%(\mathrm{n}=15)$ & $8.33(3.71-18.69)$ & $<0.0001$ \\
\hline
\end{tabular}




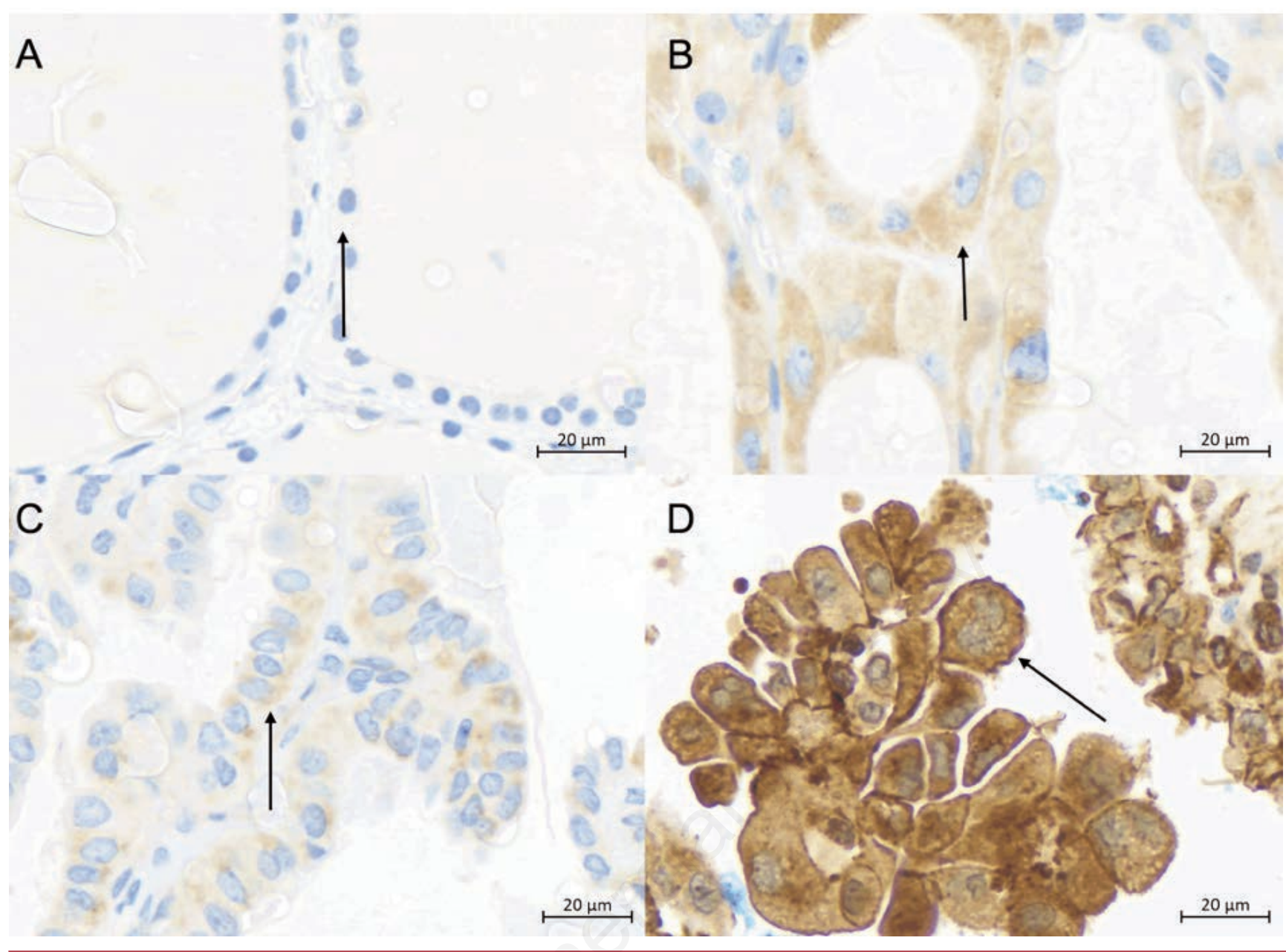

Figure 1. Immunohistochemical features of CD133 and ABCB5 in goiter and papillary carcinoma. A-D) Representative photomicrographs of goiter and papillary carcinoma, including (A) negative CD133 expression (arrow) in goiter; B) weak ABCB5 cytoplasmic expression (arrow) in goiter; C) weak CD133 cytoplasmic expression (arrow) in papillary carcinoma, and (D) strong ABCB5 cytoplasmic and membrane positivity (arrow) in papillary carcinoma.

\section{Acknowledgments}

We thank Milena Braga-Basaria, MD (Voxmed Medical Communications) for critically reviewing and suggesting improvements to the manuscript.

\section{References}

1. Lastra RR, LiVolsi VA, Baloch ZW. Aggressive variants of follicular cell-derived thyroid carcinomas: a cytopathologist's perspective. Cancer Cytopathol 2014;122:484-503.

2. Lam AK, Lo CY, Lam KS. Papillary carcinoma of thyroid: A 30 -yr clinicopathological review of the histological variants. Endocr Pathol 2005;16:323-30.

3. Baloch Z, LiVolsi VA, Tondon R. Aggressive variants of follicular cell derived thyroid carcinoma; the so called 'real thyroid carcinomas'. J Clin Pathol 2013;66:733-43.

4. Amin MB, Edge SB, American Joint Committee on Cancer. AJCC cancer staging manual. Eighth edition. Cham: Springer; 2017.

5. Nie X, Tan Z, Ge M, Jiang L, Wang J, Zheng C. Risk factors analyses for lateral lymph node metastases in papillary thyroid carcinomas: a retrospective study of 356 patients. Arch Endocrinol Metab 2016;60:492-9.

6. Kupferman ME, Patterson M, Mandel SJ, LiVolsi V, Weber RS. Patterns of lateral neck metastasis in papillary thyroid carcinoma. Arch Otolaryngol Head Neck Surg 2004;130:857-60.

7. Haugen BR, Alexander EK, Bible KC, Doherty GM, Mandel SJ, Nikiforov YE, et al. 2015 American Thyroid Association Management Guidelines for Adult Patients with Thyroid Nodules and Differentiated Thyroid Cancer: The American Thyroid Association Guidelines Task Force on Thyroid Nodules and Differentiated Thyroid Cancer. Thyroid 2016;26:1-133.

8. Gazzaniga P, Cigna E, Panasiti V, Devirgiliis V, Bottoni U, Vincenzi B, et al. CD133 and ABCB5 as stem cell markers on sentinel lymph node from melanoma patients. Eur J Surg Oncol 2010;36:1211-4.

9. Allegra A, Alonci A, Penna G, Innao V, Gerace D, Rotondo F, et al. The cancer stem cell hypothesis: a guide to potential molecular targets. Cancer Invest 2014;32:470-95.

10. Zhao Y, Peng J, Zhang E, Jiang N, Li J, Zhang Q, et al. CD133 expression may be useful as a prognostic indicator in colorectal cancer, a tool for optimizing therapy and supportive eviden- 
ce for the cancer stem cell hypothesis: a meta-analysis. Oncotarget 2016;7:10023-36.

11. Zakaria N, Yusoff NM, Zakaria Z, Lim MN, Baharuddin PJ, Fakiruddin KS, et al. Human non-small cell lung cancer expresses putative cancer stem cell markers and exhibits the transcriptomic profile of multipotent cells. BMC Cancer 2015; $15: 84$.

12. Decaussin-Petrucci M, Deladoey J, Hafdi-Nejjari Z, Sassolas G, Borson-Chazot F, Abu-Khudir R, et al. Expression of CD133 in differentiated thyroid cancer of young patients. J Clin Pathol 2015;68:434-40.

13. Frank NY, Margaryan A, Huang Y, Schatton T, Waaga-Gasser AM, Gasser M, et al. ABCB5-mediated doxorubicin transport and chemoresistance in human malignant melanoma. Cancer Res 2005;65:4320-33.

14. Yang M, Li W, Fan D, Yan Y, Zhang X, Zhang Y, et al. Expression of ABCB5 gene in hematological malignances and its significance. Leuk Lymphoma 2012;53:1211-5.

15. Guo Q, Grimmig T, Gonzalez G, Giobbie-Hurder A, Berg G, Carr N, et al. ATP-binding cassette member B5 (ABCB5) promotes tumor cell invasiveness in human colorectal cancer. $\mathrm{J}$ Biol Chem 2018;293:11166-78.

16. Lloyd RV, Osamura RY, Klöppel Gn, Rosai J, World Health Organization, International Agency for Research on Cancer. WHO classification of tumours of endocrine organs. 4th edi- tion. ed. Lyon: International Agency for Research on Cancer (IARC); 2017.

17. Pisanu A, Saba A, Podda M, Reccia I, Uccheddu A. Nodal metastasis and recurrence in papillary thyroid microcarcinoma. Endocrine 2015;48:575-81.

18. Lin Z, Lu X, Li W, Sun M, Peng M, Yang H, et al. Association of cancer stem cell markers with aggressive tumor features in papillary thyroid carcinoma. Cancer Control 2015;22:508-14.

19. Han SA, Jang JH, Won KY, Lim SJ, Song JY. Prognostic value of putative cancer stem cell markers (CD24, CD44, CD133, and ALDH1) in human papillary thyroid carcinoma. Pathol Res Pract 2017;213:956-63.

20. Cordero-Barreal A, Caleiras E, Lopez de Maturana E, Monteagudo M, Martinez-Montes AM, Leton R, et al. CD133 expression in medullary thyroid cancer cells identifies patients with poor prognosis. J Clin Endocrinol Metab 2020;105: dgaa527.

21. Wang C, Wang Z, Liu W, Ai Z. CD133 promotes the selfrenewal capacity of thyroid cancer stem cells through activation of glutamate aspartate transporter SLC1A3 expression. Biochem Biophys Res Commun 2019;511:87-91.

22. Cheung ST, Cheung PF, Cheng CK, Wong NC, Fan ST. Granulin-epithelin precursor and ATP-dependent binding cassette $(\mathrm{ABC}) \mathrm{B} 5$ regulate liver cancer cell chemoresistance. Gastroenterology 2011;140:344-55.

Received for publication: 29 May 2020. Accepted for publication: 3 November 2020.

This work is licensed under a Creative Commons Attribution-NonCommercial 4.0 International License (CC BY-NC 4.0).

(C) Copyright: the Author(s), 2020

Licensee PAGEPress, Italy

European Journal of Histochemistry 2020; 64:3143

doi:10.4081/ejh.2020.3143 